\title{
KEPEMILIKAN INSTITUSIONAL, KEPEMILIKAN MANAJERIAL, DAN KUALITAS AUDIT TERHADAP MANAJEMEN LABA
}

\author{
Inne Aryanti \\ innearyanti132@gmail.com \\ Farida Titik Kristanti \\ Hendratno \\ Universitas Telkom
}

\begin{abstract}
The purpose of this research is to understand the influence of institutional ownership, managerial ownership, and audit quality for earnings management. The unit analysis in this research is the report of a finance company sub sector coal listed Indonesia Stock Exchange. The sampling technique of this research is used by purposive sampling and obtained 8 sub-sector coal companies in 20122015 to obtain 32 samples as observation material. Methods of data analysis in this research is panel data regression. The results showed that institutional ownership has no significant effect on earnings management, while managerial ownership influence significantly the negative direction and quality of the audit significant influence with a positive direction to earnings management so for investors should choose a company with a large managerial ownership and due attention to the quality of KAP being an independent auditor of a company that does not take the wrong investment decisions.
\end{abstract}

Keyword : institutional ownership, managerial ownership, audit quality, earning management

Abstrak

Penelitian ini bertujuan untuk mengetahui pengaruh kepemilikan institusional, kepemilikan manajerial, dan kualitas audit terhadap manajemen laba. Unit analisis dalam penelitian ini adalah laporan keuangan perusahaan sub sektor batubara yang terdaftar di Bursa Efek Indonesia. Teknik pemilihan sampel menggunakan purposive sampling dan diperoleh 8 perusahaan sub sektor batubara tahun 2012-2015 sehingga didapat 32 sampel sebagai bahan observasi. Metode analisis data dalam penelitian ini adalah regresi data panel. Hasil penelitian menunjukan bahwa kepemilikan institusional tidak berpengaruh secara signifikan terhadap manajemen laba, sedangkan kepemilikan manajerial berpengaruh secara signifikan dengan arah negatif dan kualitas audit berpengaruh signifikan dengan arah positif terhadap manajemen laba sehingga investor dalam berinvestasi sebaiknya memilih perusahaan dengan kepemilikan manajerial yang besar dan memperhatikan jasa KAP yang menjadi auditor independen suatu perusahaan agar tidak mengambil keputusan investasi yang keliru.

Kata Kunci : kepemilikan institusional, kepemilikan manajerial, kualitas audit, manajemen laba 


\section{PENDAHULUAN}

Saat ini, hampir di setiap perusahaan menerapkan pemisahan kerja antara pemegang saham (principal) dengan manajemen (agen) yang disebut Teori Agensi dimana manajemen sebagai pengelola yang menangani perusahaan secara langsung diyakini lebih mengetahui informasi mengenai kondisi perusahaan dibandingkan dengan pemegang saham. Kondisi demikian, dapat menyebabkan timbulnya konflik antara keduanya yang disebabkan karena adanya perbedaan kepentingan, terutama mengenai masalah laporan keuangan yang dibuat oleh manajemen. Informasi mengenai kondisi perusahaan yang lebih banyak diketahui oleh manajemen inilah yang dapat memberi kesempatan kepada manajemen untuk melakukan tindakan yang dapat menguntungkan dirinya sendiri. Tingkat laba sering kali menjadi target manajemen untuk mencapai tujuan tertentu karena laba sering digunakan oleh para pemegang saham sebagai indikator untuk menilai kinerja perusahaan. Oleh karena itu, manajemen akan termotivasi untuk mengambil kebijakan akuntansi yang dapat berdampak pada perubahan angka laba dalam laporan keuangan yang sering disebut sebagai tindakan manajemen laba. Dengan tingkat laba yang besar pemegang saham akan menilai baik kinerja manajemen karena dianggap dapat mengelola dan memanfaatkan sumber daya dengan efektif dan efisien.

Menurut Sulistyanto (2014:51) manajemen laba adalah aktivitas manajerial untuk "mempengaruhi" dan mengintervensi laporan keuangan. Kasus manajemen laba akhir-akhir ini sering terjadi pada perusahaan sub sektor batubara yang sedang mengalami penurunan pertumbuhan kinerja dan penurunan harga semenjak tahun 2011. Sebagai contoh, pada tahun 2013 PT Garda Tujuh Buana Tbk dituding melakukan manipulasi laba dengan memasukkan penjualan lain-lain di dalam laporan keuangannya. Penjualan lain-lain ini belum tentu dibenarkan dalam standar pencatatan akuntansi karena tidak memiliki biaya dimana pembeli melakukan sendiri kegiatan penambangan batubara sehingga lebih tepat dicatat ke dalam pos pendapatan sewa. Selain itu, terjadi ketidaktepatan pengakuan pendapatan uang muka dimana uang muka diperuntukkan untuk penjualan selama 3 tahun sehingga perusahaan hanya boleh mencatat pendapatan untuk tahun yang bersangkutan.

Penelitian mengenai faktor-faktor yang mempengaruhi tindakan manajamen laba telah sering dilakukan. Namun terdapat hasil yang tidak konsisten mengenai pengaruh variabel kepemilikan institusional, kepemilikan manajerial, dan kualitas audit. Penelitian yang dilakukan oleh Welvin dan Arleen (2010) menunjukkan bahwa kepemilikan institusional tidak berpengaruh terhadap manajemen laba, sedangkan hasil penelitian Widyastuti (2007) menunjukan bahwa kepemilikan institusional berpengaruh negatif dan signifikan terhadap manajemen laba. Penelitian lain yang dilakukan oleh Dian Agustia (2013) menunjukan bahwa kepemilikan manajerial tidak berpengaruh terhadap manajemen laba, sementara penelitian Widyastuti (2009) menunjukan hasil bahwa kepemilikan manajerial berpengaruh negatif dan signifikan terhadap manajemen laba. Hasil penelitian Rakhmadiaz dan Lestari (2014) menunjukkan bahwa kualitas audit tidak berpengaruh terhadap manajemen laba, namun penelitian Welvin dan Arleen (2010) dan Sudjatna dan Muid (2015) menunjukan hasil yang sebaliknya yaitu bahwa kualitas audit berpengaruh terhadap manajemen laba.

Berdasarkan hasil penelitian yang tidak konsisten tersebut dan kasus manajemen laba yang terjadi di perusahaan sub sektor batubara, maka peneliti tertarik melakukan penelitian kembali mengenai kepemilikan institusional, kepemilikan manajerial, dan kualitas audit untuk mengetahui pengaruhnya terhadap manajemen laba, serta bagaimana variabel-variabel tersebut dalam perusahaan sub sektor batubara.

\section{METODE}

Penelitian ini termasuk penelitian deskriptif dan verifikatif dengan menggunakan metode kuantitatif. Populasi dalam penelitian ini adalah sebanyak 23 perusahaan sub sektor batubara yang terdaftar di Bursa Efek Indonesia tahun 2012-2015. Teknik pengambilan sampel yang digunakan adalah purposive sampling yaitu teknik pemilihan sampel dengan menggunakan kriteria tertentu. Kriteria sampel dalam penelitian ini adalah sebagai berikut: (1) Perusahaan sub sektor batubara yang terdaftar di Bursa Efek Indonesia selama tahun 2012-2015. (2) Perusahaan yang konsisten berada dalam sub sektor batubara di Bursa Efek Indonesia tahun 2012-2015. (3) Perusahaan sub sektor batubara yang menerbitkan laporan keuangan secara lengkap dan konsisten selama tahun 2012-2015.

Dari kriteria sampel di atas, kemudian diperoleh 8 perusahaan yang memenuhi kriteria sebagai sampel dengan periode penelitian selama 4 tahun sehingga diperoleh 32 data observasi. Teknik analisis data yang digunakan dalam penelitian ini adalah analisis statistik deskriptif dan analisis regresi data panel. Analisis statistik deskriptif dilakukan dengan menggunakan jumlah perhitungan mean, maksimal, minimal, dan standar deviasi. Sedangkan analisis regresi data panel yang dilakukan dengan melakukan tiga pengujian yaitu uji Chow, uji Hausman, dan uji Legrange multiplier. Adapun teknik pengumpulan data yang digunakan dalam penelitian ini adalah dokumentasi dan studi kepustakaan. Operasionalisasi variabel independen dan dependen dalam penelitian ini ditunjukkan pada Tabel 1 .

\section{HASIL}

Pengujian statistik deskriptif pada penelitian ini ditunjukan pada Tabel 2. Nilai mean untuk kepemilikan 
institusional (KI) adalah sebesar 49,535\%. Hal ini dapat diartikan bahwa dari 100\% saham perusahaan sub sektor batubara, rata-rata hampir setengahnya dimiliki oleh pihak institusi. Nilai terbesar kepemilikan institusional selama periode penelitian adalah sebesar 70,718\% dimiliki oleh HRUM, sedangkan nilai terkecilnya yaitu sebesar 26,000\% dimiliki oleh BSSR.

Nilai mean kepemilikan institusional lebih besar dibandingkan standar deviasinya sehingga menjelaskan bahwa simpangan data besar yang berarti rendahnya fluktuasi data dari variabel kepemilikan institusional selama periode pengamatan yang dilakukan. Hal ini menunjukan bahwa data variabel kepemilikan institusional dapat dikatakan baik karena memiliki sebaran yang rendah dan cenderung homogen (berkelompok).

Berdasarkan Tabel 2 untuk nilai mean kepemilikan manajerial (KM) adalah sebesar 21,145\%. Hal ini dapat diartikan bahwa rata-rata pihak manajemen hanya memiliki sebagian kecil dari keseluruhan saham perusahaan sub sektor batubara yang beredar. Nilai terbesar kepemilikan manajerial selama periode penelitian adalah sebesar $66,650 \%$ dimiliki oleh BSSR, sedangkan nilai terkecilnya yaitu sebesar $0,010 \%$ dimiliki oleh HRUM.

Nilai mean kepemilikan manajerial lebih kecil dibandingkan standar deviasinya sehingga menjelaskan bahwa simpangan data kecil yang ar=tinya besarnya fluktuasi data dari variabel kepemilikan manajerial selama periode pengamatan yang dilakukan. Hal ini menunjukan bahwa data pada variabel kepemilikan manajerial dapat dikatakan memiliki sebaran yang tinggi dan cenderung heterogen (tidak berkelompok).

Selain itu, Tabel 2 juga menunjukkan bahwa nilai mean untuk kualitas audit (KA) adalah sebesar 0,656 atau dapat dikatakan bahwa lebih dari setengah perusahaan sub sektor batubara menggunakan jasa KAP bigfour sebagai auditor independennya. Nilai terbesar 1 menunjukan bahwa perusahaan yang diberikan angka 1 merupakan perusahaan yang menggunakan jasa KAP bigfour, sedangkan nilai terkecil 0 menunjukan bahwa perusahaan yang diberi angka 0 adalah perusahaan yang menggunakan jasa KAP non bigfour.

Nilai mean kualitas audit lebih besar dibandingkan standar deviasinya sehingga menjelaskan bahwa simpangan data besar yang berarti rendahnya fluktuasi data dari variabel kualitas audit selama periode pengamatan yang dilakukan. Hal ini menunjukan bahwa data variabel kualitas audit dapat dikatakan baik karena memiliki sebaran yang rendah dan cenderung homogen (berkelompok).

Nilai mean untuk variabel manajemen laba adalah sebesar -0,112 yang menunjukan bahwa perusahaan sub sektor batubara selama periode penelitian, rata-rata terindikasi melakukan tindakan manajemen laba dengan pola menurunkan angka laba karena menunjukan nilai yang negatif. Untuk nilai terbesar dan terkecil yaitu masing-masing senilai 0,147 dan -1,414 dimiliki oleh ITMG.

Nilai mean manajemen laba lebih kecil dibandingkan standar deviasinya sehingga menjelaskan bahwa simpangan data kecil yang artinya besarnya fluktuasi data dari variabel manajemen laba selama periode pengamatan yang dilakukan. Hal ini menunjukan bahwa data pada variabel manajemen laba dapat dikatakan memiliki sebaran yang tinggi dan cenderung heterogen (tidak berkelompok).

Hasil Uji Chow (Uji Signifikansi Fixed Effect) ditunjukan pada Tabel 3. Berdasarkan hasil uji chow, diperoleh nilai (cross section F) dan (cross section chi-square) masing-masing bernilai 0,0014 dan 0,0000 atau lebih kecil dari 0,05 sehingga dapat disimpulkan bahwa $\mathrm{H}_{0}$ ditolak atau penelitian ini menggunakan model fixed effect. Selanjutnya dilakukan pengujian untuk memilih model antara fixed effect atau random effect dengan menggunakan uji hausman.

Hasil Uji Hausman (Uji Signifikansi Random Effect) ditunjukan pada Tabel 4. Berdasarkan hasil uji hausman, nilai probabilitas (cross section random) sebesar 0,0000<0,05, maka sesuai dengan ketentuan pengambilan keputusan bahwa $\mathrm{H}_{0}$ ditolak atau dengan kata lain regresi data panel menggunakan model Fixed Effect. Maka model yang tepat digunakan dalam penelitian ini adalah model fixed effect.

Berdasarkan hasil uji signifikansi persamaan diketahui bahwa kepemilikan institusional, kepemilikan manajerial, dan kualitas audit memiliki pengaruh yang signifikan secara bersama-sama (simultan) terhadap manajemen laba perusahaan sub sektor batubara sebesar $61,65 \%$, sedangkan sisanya $38,35 \%$ dijelaskan oleh variabel lain di luar penelitian.

Model Fixed Effect ditunjukan pada Tabel 5. Berdasarkan Tabel 5 dapat diketahui nilai konstanta koefisien sehingga dapat dibentuk persamaan sebagai berikut:

$$
\begin{aligned}
\text { Manajemen Laba }= & -0,857637+43,03438 \mathrm{KI}-0,018684 \\
& \mathrm{KM}+0,239758 \mathrm{KA}+\mathrm{e}
\end{aligned}
$$

Variabel kepemilikan institusional memiliki nilai probabilitas sebesar 0,2203 yang lebih besar dari 0,05 maka $\mathrm{H}_{02}$ diterima artinya hasil pengujian menunjukkan bahwa variabel kepemilikan institusional tidak memiliki pengaruh yang signifikan terhadap manajemen laba.

\section{PEMBAHASAN}

Hasil penelitian ini tidak sesuai dengan kerangka pemikiran yang telah dirumuskan, sehingga hipotesis bahwa kepemilikan institusional berpengaruh secara parsial dengan arah negatif terhadap manajemen laba ditolak. Hal ini dikarenakan pada umumnya investor insitusi tidak menjalankan perannya secara efektif sebagai sophisticated investors yang dapat melakukan 
pengawasan atau monitoring terhadap kinerja manajemen untuk membatasi manajemen dalam mengambil tindakan atau kebijakan yang akan berdampak pada tindakan manajemen laba. Investor institusi hanya menjalankan perannya sebagai transient investors (pemilik sementara perusahaan) yang justru hanya berfokus pada laba yang bersifat jangka pendek saja, sehingga adanya kepemilikan institusional belum tentu dapat meningkatkan monitoring secara efektif terhadap manajemen yang akan berpengaruh pada berkurangnya kebijakan manajemen dalam melakukan manajemen laba. Hasil ini sejalan dengan penelitian yang dilakukan oleh Welvin dan Arleen (2010), Dian Agustia (2013), Metta Kusumaningtyas (2012), Werner R Murhadi (2009) yang menyatakan bahwa kepemilikan institusional tidak berpengaruh terhadap manajemen laba.

Variabel kepemilikan manajerial memiliki nilai probabilitas sebesar 0,0009 yang lebih kecil dari 0,05 maka $\mathrm{H}_{03}$ ditolak artinya hasil pengujian menunjukkan bahwa variabel kepemilikan manajerial memiliki pengaruh yang signifikan terhadap manajemen laba. Koefisien regresi pada variabel kepemilikan manajerial bernilai negatif yang menunjukkan bahwa setiap peningkatan satu satuan kepemilikan manajerial maka manajemen laba akan mengalami penurunan sebesar -0,018684. Hasil penelitian ini telah sesuai dengan kerangka pemikiran yang telah diajukan sehingga hipotesis yang menyatakan bahwa kepemilikan manajerial memiliki pengaruh secara parsial dengan arah negatif terhadap manajemen laba diterima. Atau dapat diartikan bahwa semakin tinggi kepemilikan manajerial maka tindakan manajemen laba akan semakin berkurang atau sebaliknya. Dengan adanya kepemilikan manajerial akan membuat posisi manajemen sama dengan pemilik perusahaan yang dapat menyelaraskan atau menyatukan kepentingan manajemen dengan pemegang saham sehingga manajemen akan bertindak sama seperti investor pada umumnya dan tidak akan melakukan manajemen laba agar dapat mengetahui keadaan perusahaan yang sesungguhnya. Hasil penelitian ini mendukung hasil penelitian yang dilakukan oleh Widyastuti (2009) bahwa kepemilikan manajerial berpengaruh negatif dan signifikan terhadap manajemen laba.

Variabel kualitas audit memiliki probabilitas sebesar 0,0101 yang lebih kecil dari 0,05 maka $\mathrm{H}_{04}$ ditolak artinya hasil pengujian menunjukan bahwa variabel kualitas audit memiliki pengaruh yang signifikan terhadap manajemen laba. Koefisien regresi pada variabel kualitas audit bernilai positif yang menunjukkan bahwa setiap peningkatan satu satuan kualitas audit maka manajemen laba akan mengalami peningkatan sebesar 0,239758. Hasil penelitian ini telah sesuai dengan kerangka pemikiran yang dirumuskan bahwa kualitas audit berpengaruh secara parsial terhadap manajemen laba, namun dengan arah positif. Artinya, semakin tinggi kualitas audit maka manajemen laba akan semakin besar. Hal ini dapat disebabkan karena pada umumnya perusahaan menggunakan jasa KAP bigfour atau yang berkualitas tinggi hanya untuk meningkatkan kredibilitas laporan keuangan agar dapat lebih dipercaya oleh investor namun belum dapat membatasi terjadinya manajemen laba yang dilakukan oleh pihak manajemen perusahaan. Hasil ini sejalan dengan hasil penelitian Sudjatna dan Muid (2015) yang menunjukan bahwa kualitas audit berpengaruh secara signifikan dan positif terhadap manajemen laba. Namun, hasil penelitian ini bisa disebabkan karena terdapat keterbatasan penelitian berupa proksi pengukuran kualitas audit yang hanya mengklasifikasikan berdasarkan ukuran KAP, serta keterbatasan jumlah objek yang menjadi sampel dalam penelitian.

\section{KESIMPULAN}

Secara keseluruhan, rata-rata kepemilikan institusional hampir mencapai setengah dari seluruh jumlah saham perusahaan sub sektor batubara yang beredar, sedangkan jumlah kepemilikan manajerialnya masih tergolong lebih kecil dari maksimal kepemilikan saham yang ditetapkan. Untuk kualitas audit, rata-rata perusahaan sub sektor batubara menggunakan jasa KAP bigfour sebagai auditor independen.

Hasil analisis regresi data panel menunjukan bahwa kepemilikan institusional, kepemilikan manajerial dan kualitas audit secara simultan berpengaruh signifikan terhadap manajemen laba. Secara parsial kepemilikan institusional tidak berpengaruh signifikan terhadap manajemen laba, sedangkan kepemilikan manajerial berpengaruh signifikan dengan arah negatif dan kualitas audit berpengaruh signifikan dengan arah positif terhadap manajemen laba. Hal ini menunjukan bahwa kepemilikan manajerial yang besar dan penggunaan KAP non bigfour dapat membatasi tindakan manajemen laba.

Untuk penelitian mendatang sebaiknya memperpanjang periode penelitian, menambahkan variabel independen lain untuk mengetahui pengaruhnya terhadap manajemen laba di industri yang berbeda. Bagi perusahaan, dalam menyusun laporan keuangan sebaiknya sesuai dengan keadaan yang sebenarnya tanpa memilih kebijakan akuntansi apapun yang dapat mempengaruhi nilai laba. Bagi investor sebagai pengguna laporan keuangan, berdasarkan hasil penelitian sebaiknya dalam berinvestasi memilih perusahaan dengan jumlah kepemilikan manajerial yang besar dan memperhatikan jasa KAP yang menjadi auditor independen suatu perusahaan agar tidak mengambil keputusan investasi yang keliru. Karena berdasarkan hasil penelitian ditemukan bahwa kepemilikan manajerial yang besar dan kualitas audit dapat berpengaruh secara signifikan terhadap tindakan manajemen laba, terutama pada perusahaan sub sektor batubara. 


\section{DAFTAR PUSTAKA}

Agustia, Dian. 2013. Pengaruh Good Corporate Governance, Free Cash Flow, dan Leverage Terhadap Manajemen Laba. Jurnal Akuntansi dan Keuangan. 15(1). 27-42. ISSN 2338-8137.

Agustia, Dian. 2013. Pengaruh Free Cash Flow dan Kualitas Audit Terhadap Manajemen Laba. Akrual Jurnal Akuntansi. 4(2). 105-118. e-ISSN 25026380.

Kusumaningtyas, Metta. 2012. Pengaruh Independensi Komite Audit dan Kepemilikan Institusional Terhadap Manajemen Laba. Jurnal Prestasi. 9(1). ISSN: 1411-1497.

Murhadi, R Werner 2009. Good Corporate Governance and Earning Management Practices: An Indonesian Cases. Jurnal Universitas Surabaya Indonesia SSRN.

Rakhmadiaz, Randy dan Nanik, Lestari. 2014. Pengaruh Corporate Governance dan Kualitas Audit Terhadap Manajemen Laba. Jurnal 3rd Applied Business and Engineering Conference. ISSN 2339-2053.

Sudjatna, Indiferent dan Dul Muid. 2015. Pengaruh Struktur Kepemilikan, Keaktifan Komite Audit, dan Kualitas Audit Terhadap Manajemen Laba. Diponegoro Journal of Accounting. 4(4). ISSN 2337-3806.

Sulistyanto, H Sri. 2014. Manajemen Laba: Teori dan Model Empiris. Jakarta: PT. Grasindo.

Welvin, I Guna dan Arleen, Herawaty. 2010. Pengaruh Mekanisme Good Corporate Governance, Independensi Auditor, Kualitas Audit, dan Faktor Lainnya Terhadap Manajemen Laba. Jurnal Bisnis dan Akuntansi. 36(1). 39-52. ISSN 1410-9875.

Widyastuti, Tri. 2007. Pengaruh Karakteristik Perusahaan Terhadap Manajemen Laba dan Dampaknya pada Return Saham. Jurnal Akuntabilitas. 7(1). 38-44. ISSN 1412-0240.

Widyastuti, Tri. 2009. Pengaruh Struktur Kepemilikan dan Kinerja Keuangan Terhadap Manajemen Laba. Jurnal Maksi. 9(1). 30-41. ISSN 1412-6680.

http://www.bisnis.com

http://www.bi.go.id

http://www.finance.detik.com

http://www.antaranews.com
Tabel 1. Operasionalisasi Variabel

\begin{tabular}{|c|c|c|}
\hline Variabel & Indikator & Skala \\
\hline \multirow{3}{*}{$\begin{array}{l}\text { Kepemilikan } \\
\text { Institusional } \\
\left(\mathrm{X}_{1}\right)\end{array}$} & jumlah saham & \multirow{3}{*}{ Rasio } \\
\hline & institusional & \\
\hline & total saham beredar & \\
\hline \multirow{2}{*}{$\begin{array}{l}\text { Kepemilikan } \\
\text { Manajerial } \\
\left(\mathrm{X}_{2}\right)\end{array}$} & jumlah saham manajer & \multirow{2}{*}{ Rasio } \\
\hline & total saham beredar & \\
\hline $\begin{array}{l}\text { Kualitas } \\
\text { Audit }\left(\mathrm{X}_{3}\right)\end{array}$ & $\begin{array}{c}\text { KAP Big Four }=1 \\
\text { KAP non Big Four }=0\end{array}$ & Nominal \\
\hline \multirow{2}{*}{$\begin{array}{l}\text { Manajemen } \\
\text { Laba }(Y)\end{array}$} & $T A C_{i, t}$ & \multirow{2}{*}{ Rasio } \\
\hline & 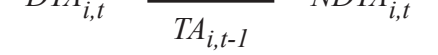 & \\
\hline
\end{tabular}

Tabel 2. Hasil Pengujian Statistik Deskriptif 2012-2015

\begin{tabular}{lcccc}
\hline & KI & KM & KA & ML \\
\hline Mean & 49.535 & 21.145 & 0.656 & -0.112 \\
Maximum & 70.718 & 66.650 & 1.000 & 0.147 \\
Minimum & 26.000 & 0.010 & 0.000 & -1.414 \\
Std. Dev & 16.213 & 27.250 & 0.483 & 0.269 \\
Observations & 32 & 32 & 32 & 32 \\
\hline
\end{tabular}

Sumber: data diolah

Tabel 3. Hasil Uji Chow (Uji Signifikansi Fixed Effect)

\begin{tabular}{lrrl}
\hline \multicolumn{1}{c}{ Effects Test } & \multicolumn{1}{c}{ Statistic } & d.f. & Prob. \\
\hline Cross-section F & 5.243581 & $(7,21)$ & 0.0014 \\
Cross-section Chi-square & 32.346320 & 7 & 0.0000 \\
\hline
\end{tabular}

Sumber: data diolah

Tabel 4. Hasil Uji Hausman (Uji Signifikansi Random Effect)

\begin{tabular}{cccc}
\hline Test Summary & $\begin{array}{c}\text { Chi-Sq. } \\
\text { Statistic }\end{array}$ & $\begin{array}{c}\text { Chi-Sq. } \\
\text { d.f. }\end{array}$ & Prob. \\
\hline Cross-section random & 27.709989 & 3 & 0.0000 \\
\hline
\end{tabular}

Sumber: data diolah

Tabel 5. Model Fixed Effect

\begin{tabular}{lrrrl}
\hline Variable & Coefficient & Std. Error & t-Statistic & Prob. \\
\hline C & -0.857637 & 0.778853 & -1.101153 & 0.2833 \\
KA & 0.239758 & 0.084780 & 2.827993 & 0.0101 \\
KI & 43.03438 & 34.06569 & 1.263276 & 0.2203 \\
KM & -0.018684 & 0.004818 & -3.878317 & 0.0009 \\
\hline Sumber:
\end{tabular}

Sumber: data diolah 